\title{
Business angel post-investment activities: a multi-level review
}

Fili, Andreas and Grünberg, Jaan.

Postscript of paper published in Journal of Management and Governance,

DOI 10.1007/s10997-014-9296-7

In this article, empirical research on post-investment activities of business angels is reviewed and conceptualized as five distinct governance processes: boundary spanning, structuring, leadership, doing, and monitoring. These processes have the potential to reduce the exposure of business angels to relational risk and market risk. The identification of these governance processes also contributes towards understanding the social aspect of business angels’ post investment involvement. In particular, it is shown how the recognition of the cognitive/institutional dimension opens up for new questions about post-investment involvement. Finally, it is proposed that venture performance can be enhanced in practice if business angels and venture members develop skills that are connected to the governance processes.

Keywords: review, business angels; post-investment involvement; governance processes; organizational membership 


\section{Introduction}

It is well known that business angels play an important economic role in the creation of entrepreneurial ventures, by providing financial and non-financial value (Kelly 2009). Estimates from different countries suggest that the amount invested by business angels in start-up and early-stage ventures equals or surpasses that of formal venture capital (Avdeitchikova 2008; Mason and Harrison 2000; Riding 2005; Sohl 2003). Although business angels are heterogeneous in their individual characteristics, most studies agree that it is after having invested, through their involvement in the venture, that they create value, as evidenced in studies of the perceptions of venture founders (Lindström and Olofsson 2001; Lindström and Olofsson 2002; Müller and Zimmermann 2009), as well as in quantitative studies wherein it is demonstrated that the number of negative exits are reduced (Wiltbank 2005). While this value creation has attracted considerable interest, most post-investment business angel research has been descriptive (Harrison and Mason 2008a), and post-investment involvement has been described as a black box (De Clerq and Manigart 2007).

One solution to establishing a stronger theoretical foundation would be through more rigorous research designs, such as through stricter sampling procedures (Avdeitchikova, Landström and Månsson 2008; Harrison and Mason 2008a). Another approach - the one chosen here - is to establish connections between business angel research and other theoretical traditions, with the aim of broadening the current understanding of business angels and of adding theoretical depth (cf. Leitch, Hill and Harrison 2010). Because the business angel’s investment relationship typically lasts many years, a prolonged post-investment coordination of effort organizing - is implied between investor and investee, suggesting that it could be useful to conceptualize business angel activities in terms of governance processes. This aim is in line with current developments in research on business angels that emphasize the social aspects in 
the investment process (see Bammens and Collewaert, forthcoming) and the role of the institutional environment (Bruton et al. 2010).

The purpose of the article is to use established concepts from organizational research to show the significance of social processes in the post-investment involvement of business angels. This is achieved through a qualitative review of empirical research on post-investment activities of business angels, wherein the activities of business angels are thematically grouped and conceptualized in terms of distinct governance processes.

The article is organized as follows. Next, in section 2, the concept of business angel postinvestment activities is clarified and defined as a phenomenon that needs to be studied at multiple analytical levels. In the subsequent section on method, section 3 , the concept of a qualitative review is discussed, and an account of the review process is provided. In section 4, the post-investment activities of business angels are conceptualized as distinct governance processes employed to handle relational and market risk. This is followed by a discussion, section 5, which focuses on the cognitive dimension of business angel activities by highlighting three themes where a more profound analysis of cognitive processes could contribute. In our conclusions, section 6, we consider the implications for practice and research.

\section{Theoretical overview: situating business angels in an organizational context}

\subsection{Business angels and investments in ventures}

A business angel has been defined as "a high net worth individual, acting alone or in a formal or informal syndicate, who invests his or her own money directly in an unquoted business in which there is no family connection and who, after making the investment, generally takes an 
active involvement in the business, for example, as an advisor or member of the board of directors” (Harrison and Mason 2008b, p. 309). Whereas the formal venture capital market consists of firms that invest capital supplied by other investors (Sahlman 1990), in contrast, the informal market for venture capital consists of actors who invest their own capital. Family investors are distinguished from business angels because it has been shown that family ties have particular effects on the investment relationship (cf. Riding 2008). From all over the world, studies show that typical business angels are wealthy, middle-aged men, with an entrepreneurial background, who invest in geographically proximate ventures, and often invest together with other business angels they know personally (Kelly 2009). Business angels view themselves as entrepreneurs rather than investors, and many of them have solid personal entrepreneurial experience (Harrison et al. 2007; Landström 1998; Politis and Landström 2002).

The investment process of business angels has been described as a stepwise process (Paul, Whittam and Wyper 2007 ), which is in line with work on formal venture capital (Tyebjee and Bruno 1984, Fried and Hisrich 1994), see Table 1 for a comparison of these steps in venture capital and business angel investments. This process involves potential investments being brought to the attention of the investor with a select few singled out for in-depth evaluation. After evaluation, for those ventures perceived as promising, the terms of investment are negotiated. After investment, post-investment involvement ensues. During post-investment involvement, an investor will typically try to maximize the value of the investment before an exit is made.

Insert Table 1 here 


\subsection{The post-investment activities of business angels}

Focusing on post-investment involvement, it has been suggested that business angels do not vary their post-investment behavior very much among different ventures in spite of contextual variations (Avdeitchikova 2008). Still, they are a rather heterogeneous group in terms of investment activity and investment involvement (Sörheim and Landström 2001) as well as in their individual motivations for investing (Baty and Sommer 2002; Sullivan and Miller 1996). As a consequence, it could be expected that the ways they get involved during postinvestment involvement would vary between business angels. It is known that business angels devote considerable attention to post-investment activities, primarily through managing the venture (Paul, Whittam and Wyper 2007). In general, the focus is on proactive involvement rather than reactive management by exception (Ehrlich et al. 1994; van Osnabrugge 1998), and there is no difference between experienced and inexperienced business angels (van Osnabrugge, 1998).

From around the world, empirical reports on the involvement of business angels in the postinvestment phase are consistent. Beginning with the much-cited seminal paper by Wetzel (1983), it has been reported that business angels normally take an official position on the venture board of directors (Erikson and Sörheim 2005; Freear, Sohl, and Wetzel 1995; Landström 1993; Madill, Haines, and Riding 2005; Mason and Harrison 1996; Prowse 1998; Sörheim and Landström 2001; Wetzel 1983), and become involved through a consulting role (cf. Sohl 1999) or, more seldom, through employment in the venture (cf. Freear, Sohl, and Wetzel 1995; Mason and Harrison 1996). 
Research on post-investment business angel activities was reviewed by Politis (2008) and summarized in a sorting logic of four distinct value-added business angel roles: the sounding board/strategic role, the resource acquisition role, the monitoring/supervision role, and the mentoring role. These four roles are based on two dimensions. The first dimension is whether the contribution of the business angel is through human capital or through social capital. Human capital is the knowledge and skills of the business angel, accumulated during experience and training, and social capital is the reputation of the business angel as "a trustworthy and competent businessperson” (Politis 2008, p. 139). The second dimension captures the focus of the business angel: internally oriented governance or externally oriented provision of resources. Although these four roles are seen as distinct, it is likely that there are connections, overlaps, tensions, and dynamics among the four roles that are yet to be discovered (Politis 2008, pp. 140-141). Presently it is suggested that in order to approach the issue of such overlaps between the roles multiple analytical levels need to be considered. A framework for this is provided in the next section.

\subsection{Key concepts of the review}

Handling risk and uncertainty is a complex problem for business angels since new firms or firms in the early stages of development are particularly exposed to uncertainty, and many fail while still young (Headd 2000; Katz and Gartner 1988; Stinchcombe 1965). Drawing on the alliance literature (Das and Teng 1998), uncertainty from the point of view of the business angel is captured by two risk concepts. The relational risk, whether the venture will behave according to its agreement with the business angel, and the market risk, the risk that the venture will be unsuccessful in its market offering (Das and Teng 1998). In line with agency theory one way for business angels to handle relational risk is through contracting (cf. Jensen 
and Meckling 1976). It is however immediately obvious that market risk cannot be handled by contract and, as critics of agency theory perspectives point out, it is not the only tool for mitigating relational risk in organizations where facilitative efforts play an important role for successful outcomes (Nilakant and Rao 1994). In other words, when the market risk and relational risk are considered together in the analysis of business angels' governance in the post-investment phase establishing causality becomes complex.

Such complexity is not surprising given the contributions from the research on the sociology of entrepreneurship which underscore the social embeddedness of actions in and structures of ventures (Thornton 1999). A useful way of analyzing this complexity was suggested by Ruef and Lounsbury (2007) who brought contextual, behavioral, constructivist, and ecological perspectives on entrepreneurship together in a multi-level framework. Two key contributions of their framework is to integrate micro and macro perspectives by introducing multiple levels of analysis as well as recognizing that entrepreneurial processes have both material/resource as well as cognitive/institutional dimensions. Figure 1 presents a simplified version of this framework.

Insert Figure 1 here

For the purposes of the present review we will use these two key elements from Ruef and Lounsbury's framework. First is the recognition that each process is active primarily at a single, specific level. In the post-investment phase business angels may try to mitigate relational and market risk through various activities, such as helping out with tasks, providing 
access to network contacts, or giving feedback on strategy. Each of these activities can be situated at a certain level of the model. Taking the roles reported by Politis (2008) as an example, the resource acquisition role would be found at the environmental level, while the sounding board/strategic role would be plotted at the organizational level.

The second element we retain from the model is the idea that processes have both material and cognitive dimensions. The material/resource dimension focuses on financial flows and physical resources, whereas the cognitive/institutional dimension includes the micro processes of thinking, making sense, and feeling, as well as the macro aspects of the institutional and cultural context. Thus, the material dimension of introducing lean production is the decreased need for resources, while the cognitive dimension at the individual level is the change in perceptions resulting from implementing lean production, and the cognitive dimension at the organizational level is the way that the organization is perceived by stakeholders as a result from implementing lean.

The levels and dimensions should not be seen as isolated from each other. Influences run vertically between the environment and the individual level, but also horizontally between the material and cognitive dimensions. The model thus encourages analyses of the dynamic between cognitive and material aspects of organizing (Weick 1969; 1995), as well as linkages between the environmental macro level and the individual micro level. Below this insight is employed to identify five distinct governance processes (boundary-spanning, structuring, leadership, doing, and monitoring) that business angels use to influence ventures in the postinvestment phase. 


\section{Method}

\subsection{Qualitative reviews}

In order to conceptualize the current research on business angel post-investment activities as organizing, a qualitative review (meta-synthesis) was performed. Whereas meta-analyses are methods for conducting quantitative literature reviews (cf. Aguinis et al. 2011), “meta syntheses are integrations that are more than the sum of parts, in that they . . . are inferences derived from taking all of the reports in a sample as a whole” (Thorne et al. 2004, p. 1358). The collective findings in the review are used as raw data and analyzed for themes and patterns that are presented in a synthesis. The quality of the review depends on the quality of the studies reviewed, as well as the transparency in decisions and interpretations made. Using the findings in published studies as data ensures transparency in that others can access the same data easily (Weed 2005).

\subsection{The identification of papers to include in the review}

Employing a purposive sampling strategy (Booth 2006), we defined the sample as the conceptual core knowledge of both quantitative and qualitative empirical research on business angel post-investment involvement. The plan was to identify a natural starting point in the literature, a place where many business angel scholars publish their studies, and then use these studies to identify other studies through snowballing of references.

The concept of “core journals” (cf. Alavi and Carlson 1992; Conroy et al. 1995) was used as a starting point. It has been suggested that a small number of core journals often manage to capture the core knowledge in the area ("Bradford's Law of Scattering," quoted in Fell et al. 
2011, p. 203). Three core journals were chosen: Venture Capital, Journal of Business Venturing, and Entrepreneurship: Theory \& Practice. Protocol searches on variants of key words such as business angels and informal investors were conducted and a number of papers were identified in these core journals, as a starting point. In a second stage, the references found in these papers were investigated in order to identify papers from other journals as well. The goal was to identify as many papers as possible (cf. Greenhalgh and Peacock 2005). No time limits were applied, and the data gathering procedure was repeated until saturation occurred (cf. Bowen 2008), meaning that no new studies were identified upon repetition of the data gathering procedures. A description of the snowballing procedure is provided in Table 2.

Insert Table 2 here

$* * *$

In parallel to this iteration, some of the papers were cited in nearly all other papers. For each such paper, a search was conducted in Google Scholar, and the Google Scholar function Cited by was used to identify other potentially interesting papers within the field.

A two-stage screening process was employed: during the first stage, papers were gathered that pertained to business angels, informal investors, or private equity post-investment involvement. Private equity was included as a search term because a number of early papers on business angels were published under the title of private equity (cf. Fenn and Liang 1998). Any papers that at a glance clearly did not contain business angel post-investment activities 
were discarded during stage one. These procedures yielded a final list of approximately 70 papers.

The subsequent second screening was conducted manually by the authors. In order to maintain high integrity in the findings included, a prerequisite for a high-quality qualitative review, material was restricted to peer-reviewed papers, in refereed journals, written in English, and most importantly: reporting original empirical data on business angels' activities during post-investment venture involvement. The second screening brought down the number of papers to 31, but after two papers focusing on dysfunctional business angel behavior had also been excluded, the final number was 29. The dysfunctional activities are not treated in the analysis, but discussed briefly.

The papers under review are listed alphabetically by author in Table 3. In the subsequent analysis, the papers are discussed thematically.

Insert Table 3 here

\subsection{The review process}

A summary of the 29 papers was written, as a first step of "engaging the data” (Locke, Golden-Biddle and Feldman 2004), using the vocabulary and terminology inherent in the papers. The content was subsequently manually coded for thematic content (Thomas and Harden 2008) and grouped according to the levels from the model: environment, organization, 
and individual. After that, the groups of activities were conceptualized in terms of organizing, connecting them to well-established theory. The conceptualization iterated between reading the original papers, reading the thematic level summary, grouping themes, and coding them in terms of organization theory. The aim was to arrive at such basic governance processes that no new empirical activities could be conceived that did not fit into one of them.

In line with the "peer debriefing” technique for ensuring trustworthiness of qualitative research (Shah and Corley 2006), drafts of the review have been read and critiqued by colleagues locally and internationally within the field of entrepreneurial finance as well as within the field of organization theory and management. More specifically, by allowing colleagues into the coding process, assumptions are made explicit (Charmaz 2005). The coded material was subjected to two formal research seminars, at different times, at two different universities.

\subsection{Limitations}

In the present paper, the analysis is restricted to business angels. Some readers may raise the objection that a delimitation to business angels is too restrictive, since many formal venture capital firms have investment managers who engage in similar post-investment activities towards their ventures. It is true that there are similarities. From an agency perspective, however, the incentive structure in a formal VC investment relationship, where the investment manager is merely managing someone else’s funds, is quite different from the incentive structure of the business angel, investing his/her own funds. It has been argued that the fact that the business angel invests his/her own funds holds strong symbolic value in the eyes of the venture. This symbolic difference can be assumed to influence the way that activities are 
perceived by the venture. Therefore, it cannot be ruled out that ventures perceive business angels and VC firm investment managers differently, even when their activities are similar.

A second reason for only reviewing business angels in this paper is to maintain conceptual clarity in research. We believe that future research on business angels as well as formal VC may benefit from reviews where the two communities are studied separately.

A limitation of only studying the findings of other studies is that findings are abstract. Empirical studies stating that business angels get involved through board membership, consultancy, and/or part-time employment actually tells us only what type of contract there is between the business angel and the venture. For example, the abstract finding board membership can be translated from a multitude of actual behaviors found in the raw data: formal - such as the allocation of voting rights (Prowse 1998); and informal - such as mentoring the CEO from a board position (Sohl 1999). Reconceptualizing the findings of others means that there is no access to such raw data, but great care has been taken to retransfer any nuances that do survive the process of abstraction from raw data into findings.

Finally, an analysis of the post-investment stage in isolation is problematic. Even though formal contracting is defined as taking place before the post-investment stage, the contract has a structuring effect on the business angel - venture relationship in specifying roles and obligations (Kelly and Hay 2003). Inter-firm relational contracts can be understood as formalized organizational processes (Furlotti 2007), which is why formal and informal approaches to risk management should be studied in relation to each other, both initially and as the relation develops over time. 


\section{Analysis of the post-investment involvement in terms of governance processes}

Next, the five governance processes through which business angels engage with ventures are presented. The analysis starts at the environmental level, with boundary spanning. The five processes possess both cognitive/institutional and a material/resource dimension, although both dimensions are not always present. For each process, the empirical findings from earlier research are linked to theoretical reasoning.

\subsection{The boundary-spanning process}

As organizations emerge and evolve they establish boundaries (Aldrich 1999), defining what is perceived as inside and outside the organization. Boundary spanning denotes an interface function operating “at the skin of the organization” (Leifer and Huber 1977), mediating between the external environment and the internal organization in an “organizational/environmental exchange” (Leifer and Delbecq 1978). Boundary-spanning roles may deal with both information processing and external representation (Aldrich and Herker 1977). One of the roles played by business angels is to handle external actors, for example, through business know-how and contacts (Mason and Harrison 1996), thereby becoming a boundary spanner. The context of new ventures is conducive to boundary spanning because since it is a common process in environments that are characterized by high uncertainty and in firms that have fluid organizational structures (Lynn 2005). 
Evidence of boundary spanning included the following activities: managing or providing/facilitating access to external resources through personal and industry networks and contacts (Ehrlich et al. 1994; Madill, Haines and Riding 2005; Sætre 2003; Sörheim 2005), providing contact with business actors (Paul, Whittam and Johnston 2003), aiding in recruiting executive personnel (Ardichvili et al. 2002; Brettel 2003; Prowse 1998; Wong, Bhatia and Freeman 2009), facilitating additional financing (Ardichvili et al. 2002; Harrison and Mason 2000; Madill, Haines and Riding 2005; Paul, Whittam and Johnston 2003; Prowse 1998; Sörheim 2005; Wong, Bhatia and Freeman 2009), providing loans and loan guarantees (Prowse 1998), providing market/business intelligence (Madill, Haines and Riding 2005), and, finally, transferring some of their social capital to the venture in providing credibility and legitimacy (Harrison and Mason 2000; Madill, Haines and Riding 2005; Sætre 2003).

Through boundary spanning, the business angel is able to expose the venture to ideas and initiatives that are in accordance with environmental norms, as a way of environmental adaptation. Conceptually, boundary spanning processes are not regular operational processes focused on the environment; instead, the boundary process is defined as all investor activities for handling and managing the environment in capacities that are not part of regular venture operations. Therefore, activities such as selling and marketing - even though directed toward the environment - should be seen as normal firm activities and not as boundary-spanning activities, even when performed by the business angel.

In the material dimension, the business angel is able to influence the inward flows of resources, such as money and people, from the venture's environment (Pfeffer and Salancik 1978). By influencing who gets recruited and if there is any money coming in or not, the business angel is able to influence the venture, thereby affecting primarily market risk. 
The cognitive-institutional dimension of boundary spanning is active in the venture's relation to the institutional environment, both through control of the information coming in, as well as through normative ideas that shape actions and by which legitimacy is created and conferred (Fiss 2008; Powell and DiMaggio 1991). Business angels provide external legitimacy for the venture simply by investing, as a way of signaling to external actors that the venture has considerable potential (Delmar and Shane 2003; Sætre 2003), but may also actively engage in a storytelling role, providing accounts to external actors about the strengths and weaknesses of the venture (cf. Lounsbury and Glynn 2001). Such activities are aimed at the environment of the organization to reduce market risk.

In summary, the boundary-spanning process in itself, with its external focus, is primarily directed at managing market risk, through a mutual, dynamic process where the organization adapts to its environment and the environment is enacted by the organization. In the specific context of business angels and ventures, the business angel helps enact the environment and helps the venture to adapt to the environment. The impact of the boundary-spanning process on relational risk is not immediately obvious since the external focus of boundary-spanning by definition is geared at market risk. We acknowledge that there may be more indirect consequences such as becoming increasingly identified with the activities of the venture.

\subsection{The structuring process}

Structuring is a process at the organizational level that has been defined as "the development, maintenance, and modification of a system of relative positions and links among actors situated in a social space” that results in "a network of stable and ongoing interaction patterns, both formal (e.g. routines and organizational units) and informal (e.g. cliques and coalitions)” 
(McEvily, Perrone and Zaheer 2003, p. 94). The structural design of an organization involves choosing a degree of vertical and horizontal differentiation as well as a degree of decentralized decision making (Jones 2007). Such formalization introduces a dysfunctional rigidity (Vlaar, Van Den Bosch and Volberda 2007) but also includes the important codification of human capital into structural capital (cf. Nonaka 1994), as the personal knowledge of organizational members is transformed into explicit, written, or otherwise codified knowledge, such as explicit rules, written manuals, work procedures, or descriptions of data. However, structuring can also be unplanned and achieved through unwritten norms. Such implicit agreements, so-called psychological contracts (Schein 1970), can be just as binding as a written agreement.

Business angels engage in structuring in several ways. They introduce and support more formalized approaches to operational and strategic work by introducing strict accounting procedures, regular reports on financial data, and operational progress and cash flow planning (Stedler and Peters 2003; Macht 2011b). The business angels are also involved in long-range planning through formulating business strategies (Ehrlich et al. 1994), developing the company’s long-term strategy (Prowse 1998), or discussing such strategies (Amatucci and Sohl 2004; Brettel 2003). Others have identified activities such as project refinement (Lindström and Olofsson 2001) and involvement in setting performance incentives (Prowse 1998). In a similar vein, the structural capital is increased as business angels help by enhancing management skills (Paul, Whittam and Johnston 2003).

There is strong empirical support for structuring as an important process in the business angel setting, as evidenced by "the need to specify roles and responsibilities in contractual form” (Kelly and Hay 2003, p. 302). Structuring is important in handling market risk, in that work 
activities both inside and outside the organization are integrated and controlled (Child 1972). The relational risk is handled by structuring since it makes the venture more transparent and manageable. The activities identified in the review emphasize the material dimension of structuring, for example routines for supply chain management and distribution logistics, yet it is well recognized that formal structure has cognitive-institutional implications by functioning as a source of external legitimacy (Meyer and Rowan 1977). Increased legitimacy in the eyes of business angels is likely to influence perceptions of relational risk.

\subsection{The leadership process}

The established conceptualizations of leadership entail leader behavior aimed at influencing followers’ goals (Stogdill 1950), performance (House 1971), and power relations (Pfeffer and Salancik 1978). Whereas the classic leader behaviors were seen in terms of two-factor models with task and relational components (Bass 1990), more recent work, new leadership, or transformational leadership (Bryman 1996; Bass 1999) emphasize the management of meaning and identity. The leadership process then comes to include a cognitive-institutional dimension where influential individuals shape the definitions of organization realities, identities, and values through, for example, visions that reflect the leader's values and his or her interpretation of the organization's mission through patterning the frames of reference and meaning of followers (Osborn, Hunt and Jauch 2002). Common to all definitions of leadership is the exertion of influence (Cogliser and Brigham 2004). Although it is usually seen as an intra-organizational influence process, it can very well exist between organizations (Connelly 2007) and in wider societal contexts (Gardner 2011). Given the role of influence processes in governance, it should not be a controversial proposition that investors can exhibit leadership behaviors. 
In part, the leadership process influences the material dimension. One of the most frequent roles taken by business angels is that of influencing decision making by acting as a sounding board (Mason and Harrison 1996) and by taking part in discussions on operations. It has been argued that business angels possess unique capabilities by virtue of the combination of separate skills and diverse knowledge in a single person (Politis 2008), an expertise (Sætre 2003) through commercial skills and entrepreneurial experience (Mason and Harrison 1996), financial know-how, marketing know-how, strategy formulation, management experience, and industry knowledge (Brettel 2003). Through the sounding board role, these skills can be utilized in venture decision making, by providing strategic advice on different subjects (Madill, Haines and Riding 2005; Mason and Harrison 1996). Paul, Whittam, and Wyper (2007) explicitly mention that Scottish business angels are able to get the best out of a team in a reference to group leadership. This focus on decision-making and groups indicates that leadership by business angels in the material dimension is a process that plays out at the organizational level, rather than on the individual.

The cognitive/institutional processes dimension is also present in the leadership process. Close relationships exist between investors and individuals in the venture, where the business angel functions in a mentoring and/or coaching capacity (Amatucchi and Sohl 2004; Brettel 2003; Sohl 1999). Mentoring and coaching have been demonstrated to be very similar to transformational leadership (Scandura and Schriesheim 1994), a leadership specifically oriented toward the growth of the followers. Moreover, it has been shown that there are frequent interactions between business angels and their ventures (cf. Lahti 2011). Through these interactions the business angel is able to promote certain perceptions and definitions over others on many levels, from strategic to operational issues. The cognitive dimension of leadership is thus more active on the individual level than the organizational. 
The leadership process is relational in both the material and cognitive dimensions and therefore primarily directed at reducing relational risk. By facilitating venture performance (by providing advice and mentoring) market risk can also be mitigated.

\subsection{The doing process}

Seminal studies of managerial work provided accounts of what managers actually do (Carlson 1951/1991, Mintzberg 1973), providing a contrast to understandings of management in terms of ideal functions. More recently, management research has come to deal with various aspects of practice, in what has been called "the practice turn” (see Miettinen, Samra-Fredericks and Yanow 2009for an overview). These two traditions alert us to what business angels are doing in ventures. Thus, the focus is on operational tasks that form part of the operations of the venture. The doing process denotes activities that are part of everyday venture practice where the business angel performs venture tasks that could be carried out by a venture member.

The review shows that business angels often reject the role of the distant investor; instead they get directly involved in the operational work in the venture (Freear, Sohl, and Wetzel 1995; Landström 1992). Wetzel (1983) identified in his survey that business angels might be employed both part- and full-time by ventures. This involvement ranges from addressing organizational issues in the venture or shaping the business model (Ardichvili et al. 2002) to providing hands-on assistance (Madill, Haines and Riding 2005) and personal involvement (Stedler and Peters 2003), through engaging in consulting help when needed (Erikson and Sörheim 2005; Freear, Sohl and Wetzel 1995; Landström 1993; Sohl 1999; Sörheim and 
Landström 2001) or solving major operational problems (Prowse 1998), technical problems (Lindström and Olofsson 2001) or evaluating capital expenditures (Prowse 1998).

The process of doing influences both relational and market risk and works in both dimensions in three different ways. The first is reducing market risk by providing superior task knowledge and carrying out these tasks better than previously done internally. The second interpretation of doing is the symbolism of a business angel getting his/her hands dirty, performing tasks customarily performed by the venture team members. If this help is received in a positive spirit, the symbolism of doing could reduce relational risk. If it is perceived in a negative way, doing is seen as meddlesome, for example as a sign of lack of trust in the capacity of the venture.

However, the third and most important interpretation of doing is as "organizational learning” (Senge 1990). It is understood as a process of mutual learning involving both explicit and tacit knowledge (Polanyi 1966). In the investment setting the knowledge shared through the frequent interaction between investors and entrepreneurs has been seen as efficient in creating mutual understanding (DeClerq and Sapienza 2001). The role of doing is most intriguing in relation to tacit knowledge. Such knowledge is unlocked by behavior and can be passed on only by working closely with someone knowledgeable over a period of time. Therefore, as a business angel cooperates with a venture team member on a specific task, tacit task knowledge could be shared. The opposite is equally true, as the venture learns from the business angel in those areas where the business angel appears to hold superior expertise. Through this transfer of tacit knowledge in both directions, doing decreases relational risk by increasing understanding and lowering the risk of misunderstanding. Thus, doing can be a 
way to access tacit knowledge and enhance coordination and control in areas that are - per definition - not directly accessible through formalization (cf. Nonaka 1994).

\subsection{The monitoring process}

In conclusion, there is the fifth process; monitoring. Whereas the other four processes can be pictured at specific levels, the monitoring process is interwoven with the other processes. Structuring specifies and defines processes and outputs, whereas the monitoring process surveys the processes and measures their outputs. Therefore, structuring provides the standards of reference for monitoring. However, boundary spanning as well as leadership both provide the business angels with access to information where both the detector and the assessor function can be brought into play. Through boundary spanning, the business angel is able to assess information on venture performance detected from external sources and compare it to internally detected information. Through leadership, the business angel is provided with opportunities to gather information and learn from venture team members, both during more formal interaction, such as meetings, but also more informally, through telephone calls, emails, social interactions, or on-site visits. The detector employed in boundary spanning and leadership is primarily restricted to explicit or even codified information, whereas monitoring performed through doing is able to tap into tacit knowledge as well.

There are both formal and informal ways to monitor the performance of an organization. Formal monitoring is, at its most basic level, defined as a formal reporting system involving a detector function and an assessor function (Anthony and Govindarajan 1995). The detector is for finding the information needed for monitoring, and the assessor is for comparing this information to various standards. 
Monitoring underlies the entire business angel investment process (Paul, Whittam and Wyper 2007). In some scholarly works, the entire post-investment stage of managing the investment is understood as nothing more than a period of monitoring venture progress (van Osnabrugge and Robinson 2000). Their perspective disregards the variations that business angels exhibit in their monitoring, from passively monitoring progress to actively intervening in the creation of such progress. Business angels engage in individual monitoring activities that include information gathering from a board position (Prowse 1998), monitoring strategy (Mason and Harrison 1996), financial and operating performance (Ehrlich et al. 1994; Stedler and Peters 2003), and the constant monitoring for signs of deterioration of the relationship (Berggren and Fili 2008) - signs signaling an increase in relational risk.

Monitoring also has a strong signaling value. Simply by measuring something, we affirm its importance (Pfeffer and Sutton 2006). Thus, not only should monitoring have a strong effect material effect on relational risk, through its potential of increasing resource efficiency, but also in the cognitive dimension, through signaling what the focus of the venture should be. Monitoring also addresses market risk, in that it involves the evaluation of the venture's competitive market performance - as well as the cognitive aspect of legitimacy.

\subsection{Summary}

The review identified five distinct governance processes (Table 4) employed to influence the venture. The processes have impact on the market and/or relational risk that the business angel is exposed to. It was further shown that the processes have both material and cognitiveinstitutional dimensions. 
Insert Table 4 here

As noted in the theoretical section of the paper, business angels are heterogeneous. Moreover, ventures are also heterogeneous, in firm development stage, industry, venture team, technology etc. In consequence, the five governance processes outlined are not likely to be employed equally by all business angels in all venture relationships. Possible variation will therefore be discussed in the next section.

\section{Discussion}

The present review explicitly connects business angel post-investment activities to three levels of analysis, in the sense that business angels involve themselves in their ventures through governance processes. Some of these processes belong to a single level, such as boundary spanning at the environmental level. Other processes, such as monitoring, can be active on several, multiple levels simultaneously; the environmental level, the organizational level, and even the individual level.

The contribution of the review is the translation of empirically based post-investment activities into distinct, theoretically derived processes. Through this conceptualization, access is provided to rich, well-established theory as well as methodological tools for conducting future research on business angels. An understanding of the interrelationships among the processes is facilitated through the use of three analytical levels and two dimensions of each level (cognitive and material). Organization theory has long acknowledged the importance of the cognitive/institutional dimension and demonstrated that the symbolic effect from doing something can far outweigh the actual, material effects of that act. A classic example would 
be the king riding into battle at the front of his army. In the material dimension, the king is just one more soldier, but in the cognitive dimension, he symbolizes much more.

For business angels, the cognitive dimension of their activities, as perceived by their ventures, is worth studying. Furthermore, it is probable that the perceptions of activities are heavily influenced by the perceptions held by the venture of the business angel him-/herself. Specifically, the trust the venture places in the business angel. In classic financial theory, such as agency theory, the investor is a principal with a status as outsider. This outsider is not trusted. However, as mentioned at the beginning of the paper, outsiders can earn trust and become insiders (Xu and Ruef 2007). The activities of an outsider are perceived differently than those of an insider.

In recognition of the importance of the cognitive dimension, the next sections $(5.1-5.3)$ illustrate this by discussing motivation in the venture, the moderating effect of organizational membership and finally dysfunctional investor behavior.

\subsection{The importance of the cognitive dimension for understanding motivation in the venture}

Each process holds a material and a cognitive aspect. Through a discussion of motivation, it will be shown that the cognitive dimension is necessary for a far more comprehensive understanding of post-investment activities. Our first example is the cognitive dimension of monitoring. While Davila and Foster (2007) show that the adoption of management control systems in early-stage start-up companies appears to increase growth in those companies, Falk and Kosfeld (2006) maintain that there are hidden costs of monitoring in terms of reduced motivation of the individuals being monitored. Thus, on the one hand, control systems provide risk reduction through structuring. But, on the other hand, the monitoring inherent in 
the same control systems could just as well increase the relational risk between investor and investee. This implies that monitoring that could potentially be considered as obtrusive by the venture, should be considered carefully. The second motivational issue is the relation between intrinsic and extrinsic motivation. The hypothesis that external incentives reduce intrinsic motivation (“crowding out”) has received strong empirical support (Bénabou and Tirole 2003), implying that there are dangers in offering monetary incentives to the venture members. If it is assumed that the entrepreneurial team, at least initially, is motivated by an intrinsic desire to achieve, a reward system based on external incentives may well decrease that intrinsic drive. The third and final example is drawn from research on empowerment (cf. Conger and Kanungo 1988). It has been suggested that the high level of uncertainty facing venture team members may create a strong sense of powerlessness in them. Such a sense of powerlessness can lead to a decrease in motivation among the venture team members, but certain empowerment techniques can be used for restoring motivation through empowering the venture team members (Conger and Kanungo 1988). Many of these techniques are entirely cognitive in nature, and therefore necessitate an understanding of the cognitive dimension of each process.

The three examples here suggest that the motivation of the venture could be damaged in the long term by careless monitoring, a rewards system based on external incentives, and not paying attention to empowerment; all of which lead to an increase in relational risk in investor-investee relations. Therefore, through understanding the cognitive dimension of processes, an understanding of the interrelationships between the processes is achieved.

\subsection{The moderating effect of organizational membership}


Another factor that may influence how the process configurations are perceived by the venture is whether the business angel is seen as an outsider or an insider by the venture. The cognitive dimension of monitoring and structuring is likely to be linked with the perceived membership status of the business angel relative the venture, as outsider or insider. Xu and Ruef (2007) show how, over time, an investor came to be perceived as trustworthy by the venture and subsequently came to be defined as an organizational insider, as part of the entrepreneurial team. As the business angel becomes an insider, relational risk is decreased. However, market risk could increase because of the adverse information effects of strong ties to the venture (Granovetter 1973). One way of becoming an insider that has been suggested in the present review is through doing. The tacit knowledge exchange from shared experience involves frames, interpretations, and shared understandings, and in sharing these, the business angel comes to be perceived as a venture insider. Another way could be when the business angel's engagement in the boundary-spanning process leads him/her to become increasingly identified with the activities of the venture.

Because an investor is perceived as either an outsider or insider, it is suggested that only those processes that are perceived as compatible with their membership status are available to each investor. Thus, certain activities are perceived as legitimate, while others are perceived as unsuitable. The concept of insider/outsider suggests that once the business angel is perceived as an insider, formal monitoring activities would be unsuitable, while leading and mentoring would be far more legitimate governance processes.

\subsection{Dysfunctional investor behavior}

A final group of issues that demonstrate the value of including the cognitive dimension of business angel activities lies in the growing body of research on "the dark side" of investor- 
investee behavior (e. g. Collewaert 2012; Macht 2011a). In these studies, post-investment involvement is not necessarily assumed to be beneficial. Such studies originated in the context of formal venture capital (Parhankangas and Landström 2004; 2006; Yitshaki 2008) and have been continued within the business angel context through studies on conflict behavior (Collewaert 2012), perceived unethical behavior (Collewaert and Fassin 2011), as well as incompetence and meddling (Macht 2011a; 2011b). Dysfunctional behavior is not always primarily symbolic. The basic form of sabotage, where someone will deliberately - physically - damage operations, has strong material repercussions.

However, it is the perceptions of activities as positive or negative in the eyes of the venture that decide whether relational risk is reduced or increased (and to a lesser extent the perceptions held by market actors / external stakeholders). Taking the work of Collewaert and Fassin (2011) as an example, the cognitive dimension is necessary to include because of the sense-making processes dealing with naming and shaming that play an important role in conflicts between entrepreneurs and investors. In this way, the cognitive aspect of activities seems decisive for understanding the positive as well as the negative effect of business angel activities.

\section{Conclusions and implications}

Our main conclusion is simple: business angels engage in five distinct governance processes, which have cognitive as well as material dimensions, in order to reduce market and relational risks. In relation to previous research, it has been shown that the cognitive/institutional dimension of post-investment involvement can impact venture performance. The preceding discussion indicated that some of the processes are not synergetic, but rather will neutralize each other if used together. Implications for practice are straightforward. Investors and 
investees should be aware that the angel-venture relation holds a significant social dimension which is captured by the five governance mechanisms. With such an awareness they can draw on knowledge and skills associated with these processes (e.g. leadership or monitoring) in order to improve venture performance. The cognitive dimension opens up for the recognition of identity processes, which our discussion of organizational membership showed. The practical implication of organizational membership is that investors should avoid the neutralizing effect of employing certain processes together. In general, investors and investees should recognize that a goal such as "understanding each other better in the post-investment relationship” is something that will increase the chances of better venture development (Cable and Shane 1997).

For research, the present review suggests several avenues for the future. The first is the study of each individual process. Focusing on the tensions and ambiguities inherent in the interplay between material and cognitive aspects within each process, may help answer when and why some processes are perceived as more legitimate than others. The second is the study of configurations of several processes employed simultaneously. It has been suggested that there are synergies between certain processes (Politis 2008). Equally important, it is suggested in the present review that some processes probably neutralize or counteract one another. Identifying and studying different process configurations would constitute the second avenue for future research. The third and last avenue of future research suggested here, is the study of the dynamics of process configurations over time: what sequences can be identified empirically, and what logics govern the choice of certain sequences over others.

In the field of formal venture capital, Shepherd and Zacharakis (2001) have proposed that achieving a good fit is a major factor affecting the health of a post-investment relationship, 
suggesting that there are configurations and sequences that fit the expectations of the other part of the relationship and are perceived as more legitimate. These studies should be undertaken with an explicit care given to whether the business angel involved is perceived as an outsider or an insider by the venture. An example of this could be an insider business angel, involved in structuring and boundary spanning, in a research-based venture entering the innovation system with science parks and incubators, and stakeholders controlling access to soft funding.

Overall, focusing on organizational processes means devoting attention to agency, change, and the embeddedness of actions in contexts (Pettigrew 1997). Presumably, specific contexts trigger the adoption of specific processes. Biographical approaches (Kimberly 1987) could be used to capture critical events in the relationship in context, and the processes employed to handle these events. Different nuances - and maybe even new phenomena - could be described through exploratory research based on interviews and observations, in studies aware of both the material and cognitive dimensions of the investor-investee relationship. 


\section{References}

Aguinis, H., Pierce, C.A., Bosco, F.A., Dalton, D.R., Dalton, C.M., 2011. Debunking Myths and Urban Legends About Meta-Analysis. Organizational Research Methods, 14, 306-331.

Alavi, M., Carlson, P., 1992. A Review of MIS Research and Disciplinary Development. Journal of Management Information Systems, 8, 45-62.

Aldrich, H., 1999. Organizations Evolving. Thousand Oaks, CA, Sage.

Aldrich, H., Herker, D., 1977. Boundary Spanning Roles and Organization Structure. The Academy of Management Review, 2, 217-230.

Amatucci, F. M., Sohl, J. E., 2004. Women entrepreneurs securing business angel financing: Tales from the field. Venture Capital, 6, 181-196.

Anthony, R.N., Govindarajan, V., 1995. Management Control Systems. 8th ed. New York, McGraw-Hill.

Ardichvili, A., Cardozo, R.N., Tune, K., Reinach, J., 2002. The Role of Angel Investors in the Assembly of Non-Financial Resources of New Ventures: Conceptual Framework and Empirical Evidence. Journal of Enterprising Culture, 10, 39-65.

Avdeitchikova, S., 2008. On the Structure of the Informal Venture Capital Market in Sweden: Developing Investment Roles. Venture Capital, 10, 55-85.

Avdeitchikova, S., Landström, H., Månsson, N., 2008. What Do We Mean When We Talk about Business Angels? Some Reflections on Definitions and Sampling. Venture Capital, 10, 371-394.

Bammens, Y., Collewaert, V., forthcoming. Trust Between Entrepreneurs and Angel Investors: Exploring Positive and Negative Implications for Venture Performance Assessments. Journal of Management, pre-published online.

Bass, B.M., 1990. Bass \& Stogdill's Handbook of Leadership. 3rd ed. New York, The Free Press.

Bass, B.M., 1999. Two Decades of Research and Development in Transformational Leadership. European Journal of Work \& Organizational Psychology, 8, 9-32.

Baty, G., Sommer, B., 2002. True Then, True Now: A 40-year Perspective on the Early Stage Investment Market. Venture Capital, 4, 289-293.

Bénabou, R., Tirole, J., 2003. Intrinsic and Extrinsic Motivation. Review of Economic Studies, 70, 489-520. 
Berggren, B., Fili, A., 2008. When Things Go Wrong: Business Angels' Use of Cues in Judging Their Investment Relations. International Journal of Business Strategy, 8, 48-58.

Booth, A., 2006. "Brimful of STARLITE”: Toward Standards for Reporting Literature Searches. Journal of the Medical Library Association, 94, 421-429.

Bowen, G.A., 2008. Naturalistic Inquiry and the Saturation Concept: a Research Note. Qualitative Research, 8, 137-152.

Bruton, G. D., Filatotchev, I., Chahine, S., Wright, M., 2010. Governance, Ownership Structure, and Performance of IPO Firms: The Impact of Different Types of Private Equity Investors and Institutional Environments. Strategic Management Journal, 31, 491-509.

Brettel, M., 2003. Business Angels in Germany: A Research Note. Venture Capital, 5, 251268.

Bryman, A., 1996. Leadership in Organizations, In: Clegg, S.R., Hardy, C., Nord, W.R. (Eds), Handbook of Organization Studies. London, Sage, 276-292.

Cable, D. M., Shane, S., 1997. A prisoner's dilemma approach to entrepreneur-venture capitalist relationships. Academy of Management Review, 22, 142-176.

Carlson, S. 1991/1951. Executive Behaviour. Reprinted with Contributions by Henry Mintzberg and Rosemary Stewart, Acta Universitatis Upsaliensis, Studia Oeconomiae Negotiorum 32, Stockholm: Almqvist \& Wiksell International.

Charmaz, K., 2005. Grounded Theory in the 21st Century: Applications for Advancing Social Justice Studies. In Denzin, N. K., Lincoln, Y. S. (Eds), The SAGE Handbook of Qualitative Research, 3 Ed. Thousand Oaks, CA: Sage, 507-536.

Child, J., 1972. Organizational Structure, Environment and Performance: The Role of Strategic Choice. Sociology, 6, 1-22.

Cogliser, C.C., Brigham, K.H., 2004, "The Intersection of Leadership and Entrepreneurship: Mutual Lessons to Be Learned", The Leadership Quarterly, 15, 771-799.

Collewaert, V. 2012. Angel Investors' and Entrepreneurs' Intentions to Exit Their Ventures: A Conflict Perspective. Entrepreneurship Theory and Practice, 36: 753-779.

Collewaert, V., Fassin, Y., 2011. Conflicts Between Entrepreneurs and Investors: the Impact of Perceived Unethical Behavior. Small Business Economics. DOI: 10.1007/s11187-0119379-7.

Conger, J. A., Kanungo, R. N., 1988. The Empowerment Process: Integrating Theory and Practice. The Academy of Management Review, 13: 471-482.

Connelly, D. R., 2007. Leadership in the collaborative interorganizational domain. International Journal of Public Administration, 30, 1231-1262. 
Conroy, M.E., Dusansky, R., Drukker, D., Kildegaard, A., 1995. The Productivity of Economics Departments in the U.S.: Publications in the Core Journals. Journal of Economic Literature, 33, 1966-1971.

Das, T.K., Teng, B.-S., 1998. Between Trust and Control: Developing Confidence in Partner Cooperation in Alliances. The Academy of Management Review, 23, 491-512.

Davila, A., Foster, G., 2007. Management Control Systems in Early-Stage Startup Companies. The Accounting Review, 82, 907-937.

De Clercq, D., Manigart, S., 2007. The Venture Capital Post-Investment Phase: Opening the Black Box of Involvement. In Handbook of research on venture capital, ed. H. Landström, Cheltenham: Edward Elgar, 193-218.

De Clercq, D., Sapienza, H. J., 2001. The creation of relational rents in venture capitalistentrepreneur dyads. Venture Capital, 3, 107-127.

Delmar, F., Shane, S., 2003. Does Business Planning Facilitate the Development of New Ventures? Strategic Management Journal, 24, 1165-1185.

Ehrlich, S.B., De Noble, A.F., Moore, T., Weaver, R.R., 1994. After the Cash Arrives: A Comparative Study of Venture Capital and Private Investor Involvement in Entrepreneurial Firms. Journal of Business Venturing, 9, 67-82.

Erikson, T., Sörheim, R., 2005. ‘Technology Angels’ and Other Informal Investors. Technovation, 25, 489-496.

Falk, A., Kosfeld, M., 2006. The Hidden Costs of Control. The American Economic Review, 96, 1611-1630.

Fell, D.W., Burnham, J.F., Buchanan, M.J., Horchen, H.A., Scherr, J.A., 2011. Mapping the Core Journals of the Physical Therapy Literature. Journal of the Medical Library Association, 99, 202-207.

Fenn, G. W., Liang, N., 1998. New Resources and New Ideas: Private Equity for Small Businesses. Journal of Banking \& Finance, 22, 1077-1084.

Fiss, P.C., 2008. Institutions and Corporate Governance, in: Greenwood, R., Oliver, C., Sahlin, K., Suddaby, R. (Eds), The Sage Handbook of Organizational Institutionalism. London: Sage, 389-410.

Freear, J., Sohl, J.E., Wetzel, W.E., 1995. Angels: Personal Investors in the Venture Capital Market. Entrepreneurship \& Regional Development, 7, 85-94.

Fried, V. H., Hisrich, R. D., 1994. Toward a Model of Venture Capital Investment Decision Making. Financial Management, 23, 2837.

Furlotti, M., 2007. There is More to Contracts than Incompleteness: a Review and Assessment of Empirical Research on Inter-Firm Contract Design. Journal of Management and Governance, 11, 61-99. 
Gardner, H., 2011. Leading Minds: An Anatomy of Leadership. New York: Basic Books.

Granovetter, M. S., 1973. The Strength of Weak Ties. American Journal of Sociology, 78, 1360-1380.

Greenhalgh, T., Peacock, R., 2005. Effectiveness and Efficiency of Search Methods in Systematic Reviews of Complex Evidence: Audit of Primary Sources. British Medical Journal, 331, 1064-1065.

Harrison, R.T., Mason, C.M., 2000. Venture Capital Market Complementarities: The Links between Business Angels and Venture Capital Funds in the United Kingdom. Venture Capital, 2, 223-242.

Harrison, R.T., Mason, C.M., 2008a. Sampling and Data Collection in Business Angel Research. Venture Capital, 10, 305-308.

Harrison, R.T., Mason, C.M., 2008b. Measuring Business Angel Investment Activity in the United Kingdom: A Review of Potential Data Sources. Venture Capital, 10, 309-330.

Harrison, R.T., Mason, C.M., Building, D.L., Street, R., 2007. Does Gender Matter? Women Business Angels and the Supply of Entrepreneurial Finance. Entrepreneurship Theory and Practice, 31, 445-472.

Headd, B., 2000. Business Success: Factors Leading to Surviving and Closing Successfully. Center for Economic Studies, Bureau of the Census.

House, R.J., 1971. A Path-Goal Theory of Leader Effectiveness. Administrative Science Quarterly, 16, 321-339.

Hunt, J. G., 1991. Leadership: A New Synthesis. Thousand Oaks, CA: Sage.

Jensen, M.C., Meckling, W.H., 1976. Theory of the Firm: Managerial Behavior, Agency Costs and Ownership Structure. Journal of Financial Economics, 3, 305-360.

Jones, G. R., 2007. Organization Theory, Design, and Change. 5 Ed., New Jersey, Pearson.

Katz, J., Gartner, W.B., 1988. Properties of Emerging Organizations. The Academy of Management Review, 13, 429-441.

Kelly, P., 2009. Business angel research: The Road Travelled and the Journey Ahead. In Handbook of Research on Venture Capital, ed. H. Landström, 315-31. Cheltenham: Edward Elgar.

Kelly, P., Hay, M., 2003. Business Angel Contracts: The Influence of Context. Venture Capital, 5, 287-312.

Kimberly, J.R., 1987. Organizations: A Biographical Approach, in: Lorsch, L.W. (Ed), Handbook of Organizational Behavior. Eaglewood Cliffs, NJ: Prentice-Hall, 223-237. 
Lahti, T., 2011. Categorization of Angel Investments: An Explorative Analysis of Risk Reduction Strategies in Finland. Venture Capital, 13, 49-74.

Landström, H., 1992, The Relationship Between Private Investors and Small Firms: An Agency Theory Approach. Entrepreneurship and Regional Development, 4, 199-223.

Landström, H., 1993. Informal Risk Capital in Sweden and Some International Comparisons. Journal of Business Venturing, 8, 525-540.

Landström, H., 1998. Informal Investors as Entrepreneurs. Decision-Making Criteria Used by Informal Investors in Their Assessment of New Investment Proposals. Technovation, 18, 321-333.

Leifer, R., Delbecq, A., 1978. Organizational/Environmental Interchange: A Model of Boundary Spanning Activity. The Academy of Management Review, 3, 40-50.

Leifer, R., Huber, G.P., 1977. Relations among Perceived Environmental Uncertainty, Organization Structure, and Boundary-Spanning Behavior. Administrative Science Quarterly, 22, 235-247.

Leitch, C.M., Hill, F.M., Harrison, R.T., 2010. The Philosophy and Practice of Interpretivist Research in Entrepreneurship: Quality, Validation, and Trust. Organizational Research Methods, 13, 67-84.

Lindström, G., Olofsson, C., 2001. Early Stage Financing of NTBF:s: An Analysis of Contributions from Support Actors. Venture Capital, 3, 151-168.

Lindström, G., Olofsson, C., 2002. Affärsänglar Och Teknikbaserade Industriföretag. Stockholm, SNS.

Locke, K., Golden-Biddle, K., Feldman, M.S., 2004. Imaginative Theorizing in Interpretive Organizational Research. Academy of Management Best Conference Paper 2004.

Lounsbury, M., Glynn, M.A., 2001. Cultural Entrepreneurship. Stories of Legitimacy and the Acquisition of Resources. Strategic Management Journal, 22, 545-564.

Lynn, M.L., 2005. Organizational Buffering: Managing Boundaries and Cores. Organization Studies, 26, 37-61.

Macht, S. A., 2011a, Inexpert Business Angels: How Even Investors with 'Nothing to Add' Can Add Value, Strategic Change, 20, 269-278.

Macht, S. A., 2011b, The Role of Investee Company Managers in Business Angels Involvement: Empirical Insights from Dyadic Data, Venture Capital, 13, 267-293.

Madill, J.J., Haines, G.H., Riding, A.L., 2005. The Role of Angels in Technology SME:s: A Link to Venture Capital. Venture Capital, 7, 107-129. 
Mason, C.M., Harrison, R.T., 1996, Informal Venture Capital: A Study of the Investment process, the Post-Investment Experience and Investment Performance. Entrepreneurship and Regional Development, 8, 105-125.

Mason, C.M., Harrison, R.T., 2000, The Size of the Informal Venture Capital Market in the United Kingdom. Small Business Economics, 15, 137-148.

McEvily, B., Perrone, V., Zaheer, A., 2003. Trust as an Organizing Principle. Organization Science, 14, 91-103.

Meyer, J.W., Rowan, B., 1977. Institutionalized Organizations: Formal Structure as Myth and Ceremony. American Journal of Sociology, 83, 340-363.

Miettinen, R., Samra-Fredericks, D., Yanow, D., 2009. Re-Turn to Practice: An Introductory Essay.Organization Studies, 30, 1309-1327.

Mintzberg, H., 1973. The Nature of Managerial Work. New York: Harper \& Row.

Müller, E., Zimmermann, V., 2009. The Importance of Equity Finance for R\&D Activity. Small Business Economics, 33, 303-318.

Nilakant, V., Rao, H., 1994. Agency theory and uncertainty in organizations: An evaluation. Organization studies, 15, 649-672.

Nonaka, I., 1994. A Dynamic Theory of Organizational Knowledge Creation. Organization Science, 5, 14-37.

Osborn, R.N., Hunt, J.G., Jauch, L.R., 2002. Toward a Contextual Theory of Leadership. The Leadership Quarterly, 13, 797-837.

van Osnabrugge, M., 1998. Do Serial and Non-Serial Investors Behave Differently?: An Empirical and Theoretical Analysis. Entrepreneurship: Theory and Practice, 22, 23-42.

van Osnabrugge, M., Robinson, R.J., 2000. Angel Investing. San Francisco, Jossey-Bass.

Parhankangas, A., Landström, H., 2004. Responses to Psychological Contract Violations in the Venture Capitalist-Entrepreneur Relationship: an Exploratory Study. Venture Capital, 6, 217-242.

Parhankangas, A., Landström, H., 2006. How Venture Capitalists Respond to Unmet Expectations: the Role of Social Environment. Journal of Business Venturing, 21, 773-801.

Paul, S., Whittam, G., Johnston, J. B., 2003. The Operation of the Informal Venture Capital Market in Scotland. Venture Capital, 5, 313-335.

Paul, S., Whittam, G., Wyper, J., 2007. Towards a Model of the Business Angel Investment Process. Venture Capital, 9, 107-125.

Pettigrew, A. M., 1997. What is Processual Analysis. Scandinavian Journal of Management, 13, 337-348. 
Pfeffer, J., Salancik, G.R., 1978. The External Control of Organizations. New York, Harper and Row.

Pfeffer, J., Sutton, R.I., 2006. Hard Facts, Dangerous Half-Truths and Total Nonsense: Profiting from Evidence-Based Management. Cambridge, MA, Harvard Business School Press.

Polanyi, M., 1966. The Tacit Dimension. London, Routledge.

Politis, D., 2008. Business Angels and Value Added: What Do We Know and Where Do We Go? Venture Capital, 10, 127-147.

Politis, D., Landström, H., 2002. Informal Investors as Entrepreneurs - the Development of an Entrepreneurial Career. Venture Capital, 4, 78-101.

Powell, W.W., DiMaggio, P.J., 1991. The New Institutionalism in Organizational Analysis. Chicago, University of Chicago Press.

Prowse, S., 1998. Angel Investors and the Market for Angel Investments. Journal of Banking and Finance, 22, 785-792.

Reitan, B., Sörheim, R., 2000. The Informal Venture Capital Market in Norway - Investor Characteristics, Behaviour and Investment Preferences. Venture Capital, 2, 129-141.

Riding, A., 2005. On the Size and Structure of the Informal Market. Working Paper, School of Business, Carleton University, Canada.

Riding, A., 2008. Business Angels and Love Money Investors: Segments of the Informal Market for Risk Capital. Venture Capital, 10, 355-369.

Ruef, M., Lounsbury, M., 2007. The Sociology of Entrepreneurship, in: Ruef, M., Lounsbury, M. (Eds), The Sociology of Entrepreneurship. Elsevier, Amsterdam, 1-32.

Sahlman, W. A., 1990. The Structure and Governance of Venture-Capital Organizations. Journal of financial economics, 27, 473-521.

Scandura, T. A., Schriesheim, C. A., 1994. Leader-Member Exchange and Supervisor Career Mentoring as Complementary Constructs in Leadership Research. Academy of Management Journal, 37, 1588-1602.

Schein, E.H., 1970. Organizational Psychology. Englewood Cliffs, NJ, Prentice-Hall.

Schäfer, D., Schilder, D., 2009. Smart capital in German start-ups-an empirical analysis. Venture Capital, 11, 163-183.

Senge, P.M., 1990. The Fifth Discipline. New York, Doubleday Currency.

Shah, S.K., Corley, K.G., 2006. Building Better Theory by Bridging the QuantitativeQualitative Divide, Journal of Management Studies, 43, 1821-1835. 
Shepherd, D.A., Zacharakis, A., 2001. The Venture Capitalist - Entrepreneur Relationship: Control, Trust and Confidence in Co-operative Behaviour. Venture Capital, 3, 129-149.

Sohl, J.E., 1999. The Early-Stage Equity Market in the USA. Venture Capital, 1, 101-120.

Sohl, J. E., 2003. The Private Equity Market in the USA: Lessons from Volatility. Venture Capital, 5, 29-46.

Stedler, H., Peters, H.H., 2003. Business Angels in Germany: An Empirical Study. Venture Capital, 5, 269-276.

Stinchcombe, A.L., 1965. Social Structure and Organizations, in: March, J.G. (Ed), Handbook of Organizations. Chicago, Rand McNally, 153-193.

Stogdill, R.M., 1950. Leadership, Membership, and Organization. Psychological Bulletin, 47, $1-14$.

Sætre, A., 2003. Entrepreneurial Perspectives on Informal Venture Capital. Venture Capital, 5, 71-94.

Sullivan, M. K., \& Miller, A., 1996. Segmenting the informal venture capital market: Economic, hedonistic, and altruistic investors. Journal of Business Research, 36, 25-35.

Sörheim, R., 2005. Business Angels as Facilitators for Further Finance: An Exploratory Study. Journal of Small Business and Enterprise Development, 12, 178-191.

Sörheim, R., Landström, H., 2001. Informal Investors - a Categorization with Policy Implications. Entrepreneurship \& Regional Development, 13, 351-370.

Tashiro, Y., 1999. Business angels in Japan. Venture Capital, 1, 259-273.

Thomas, J., Harden, A., 2008. Methods for the thematic synthesis of qualitative research in systematic reviews. BMC Medical Research Methodology, 8, Art. 45.

Thorne, S., Jensen, L., Kearney, M.H., Noblit, G., Sandelowski, M., 2004. Qualitative Metasynthesis: Reflections on Methodological Orientation and Ideological Agenda. Qualitative Health Research, 14, 1342-1365.

Thornton, P. H., 1999. The Sociology of Entrepreneurship. Annual Review of Sociology, 25, 19-46.

Tyebjee, T.T., Bruno, A.V., 1984. A Model of Venture Capitalist Investment Activity. Management Science, 30, 1051-1066.

Vlaar, P.W.L., Van Den Bosch, F.A.J., Volberda, H.W., 2007. Towards a Dialectic Perspective on Formalization in Interorganizational Relationships: How Alliance Managers Capitalize on the Duality Inherent in Contracts, Rules and Procedures. Organization Studies, 28, 437-466. 
Weed, M., 2005. “Meta Interpretation”: A Method for the Interpretive Synthesis of Qualitative Research. Forum: Qualitative Social Research, 6, Art. 37.

Weick, K.E., 1969. The Social Psychology of Organizing. Reading, MA, Addison-Wesley.

Weick, K.E., 1995. Sensemaking in Organizations. Thousand Oaks, CA, Sage.

Wetzel, W.E., 1983. Angels and Informal Risk Capital. Sloan Management Review, 24, 2334.

Wiltbank, R., 2005. Investment Practices and Outcomes of Informal Venture Investors. Venture Capital, 7, 343-357.

Wong, A., Bhatia, M., Freeman, Z., 2009. Angel finance: the other venture capital. Strategic Change, 18, 221-230.

Xu, H., Ruef, M., 2007. Boundary Formation in Emergent Organizations, in: Ruef, M., Lounsbury, M. (Eds), The Sociology of Entrepreneurship. Elsevier, Amsterdam, 125-153.

Yitshaki, R., 2008. Venture capitalist-entrepreneur conflicts: An exploratory study of determinants and possible resolutions. International Journal of Conflict Management, 19, 262-292.

Yukl, G., Lepsinger, R., 2004. Flexible Leadership: Creating Value by Balancing Multiple Challenges and Choices. San Francisco, CA, Jossey-Bass. 


\begin{tabular}{ccc}
\cline { 2 - 2 } Material- & Environmental level & Cognitive- \\
resource & Organizational level & $\begin{array}{c}\text { institutional } \\
\text { dimension }\end{array}$ \\
\cline { 2 - 3 } & Individual level &
\end{tabular}

Fig. 1 Levels and dimensions of the entrepreneurial context 
Table 1. The investment process for venture capital firms and business angels

\begin{tabular}{lll}
\hline $\begin{array}{l}\text { Tyebjee and Bruno (1984) } \\
\text { Venture capital }\end{array}$ & $\begin{array}{l}\text { Fried and Hisrich (1994) } \\
\text { Venture capital }\end{array}$ & $\begin{array}{l}\text { Paul, Whittam and } \\
\text { Wyper (2007) Business } \\
\text { angels }\end{array}$ \\
$\begin{array}{ll}\text { Deal Origination } \\
\text { Deal Screening }\end{array}$ & $\begin{array}{l}\text { Origination } \\
\text { Specific Screening } \\
\text { Generic Screen }\end{array}$ & $\begin{array}{l}\text { Familiarization } \\
\text { Screening }\end{array}$ \\
Deal Evaluation & $\begin{array}{l}\text { First-phase Evaluation } \\
\text { Second-phase Evaluation }\end{array}$ & \\
Structuring & Closing & Bargaining \\
Post-Investment Activities & & $\begin{array}{l}\text { Managing } \\
\text { Harvesting }\end{array}$ \\
\hline
\end{tabular}


Table 2. Stages in the process of identifying relevant research articles to include in the review

\begin{tabular}{llll}
\hline Stage & $\begin{array}{l}\text { Procedure for identifying } \\
\text { papers to include in the } \\
\text { review }\end{array}$ & $\begin{array}{l}\text { Source of papers } \\
\text { Initial protocol search }\end{array}$ & $\begin{array}{l}\text { Output list of } \\
\text { papers }\end{array}$ \\
\hline & $\begin{array}{l}\text { Core journals } \\
\text { fnowballing references }\end{array}$ & $\begin{array}{l}\text { All journals mentioned in } \\
\text { initial core list }\end{array}$ & $\begin{array}{l}\text { Initial core list } \\
\text { List } 2\end{array}$ \\
3 & $\begin{array}{l}\text { Snowballing references } \\
\text { from list 2 }\end{array}$ & $\begin{array}{l}\text { All journals mentioned in } \\
\text { Iteration }\end{array}$ & List 3 \\
& & & $\begin{array}{l}\text { Saturation } \\
\text { Final list to review } \\
\text { (same as Table 3) }\end{array}$ \\
\hline
\end{tabular}


Table 3. Papers included in the review

\begin{tabular}{|c|c|c|c|}
\hline Authors & Year & Data & $\begin{array}{l}\text { Key activities identified in the } \\
\text { review }\end{array}$ \\
\hline $\begin{array}{l}\text { Amatucci } \\
\text { and Sohl }\end{array}$ & 2004 & $\begin{array}{l}\text { Interviews with } 4 \\
\text { women entrepreneurs } \\
\text { with business angel as } \\
\text { investor. }\end{array}$ & $\begin{array}{l}\text { Business angels act as mentor and } \\
\text { friend, and discuss strategic issues. }\end{array}$ \\
\hline $\begin{array}{l}\text { Ardichvili et } \\
\text { al. }\end{array}$ & 2002 & $\begin{array}{l}27 \text { structured } \\
\text { interviews with } \\
\text { independent serial } \\
\text { investors. }\end{array}$ & $\begin{array}{l}\text { Business angels address } \\
\text { organizational issues in the venture, } \\
\text { shape the business model, aid in } \\
\text { recruiting executive personnel, } \\
\text { facilitate additional financing, } \\
\text { provide connections to social } \\
\text { networks, and sit on the board or } \\
\text { occupy top management positions. }\end{array}$ \\
\hline $\begin{array}{l}\text { Berggren and } \\
\text { Fili }\end{array}$ & 2008 & $\begin{array}{l}\text { Semi-structured } \\
\text { interviews with more } \\
\text { than } 20 \text { Swedish } \\
\text { business angels. }\end{array}$ & $\begin{array}{l}\text { Business angels are engaged in } \\
\text { monitoring where they scan for cues } \\
\text { of deteriorating venture relationship. }\end{array}$ \\
\hline Brettel & 2003 & $\begin{array}{l}\text { Structured interviews } \\
\text { with } 48 \text { German } \\
\text { business angels. }\end{array}$ & $\begin{array}{l}\text { Business angels are involved } \\
\text { through a supervisory board or an } \\
\text { advisory council, and they } \\
\text { participate in shareholder meetings. } \\
\text { They provide access to personal } \\
\text { networks and bring financial know- } \\
\text { how, management experience, and } \\
\text { industry knowledge to the venture, } \\
\text { by engaging in coaching, marketing, } \\
\text { strategy, and recruitment. }\end{array}$ \\
\hline Ehrlich et al. & 1994 & $\begin{array}{l}\text { Survey of } 47 \\
\text { entrepreneurs in } \\
\text { California with a } \\
\text { business angel as } \\
\text { investor. }\end{array}$ & $\begin{array}{l}\text { Business angels' most common } \\
\text { activities are to act as an interface } \\
\text { with the investor group, aid in } \\
\text { obtaining alternative equity, monitor } \\
\text { financial and operating } \\
\text { performance, act as a sounding } \\
\text { board and formulate business } \\
\text { strategy. }\end{array}$ \\
\hline $\begin{array}{l}\text { Erikson and } \\
\text { Sörheim }\end{array}$ & 2005 & $\begin{array}{l}\text { Same data set as } \\
\text { Reitan and Sörheim } \\
\text { (2000) }\end{array}$ & $\begin{array}{l}\text { Business angels are involved } \\
\text { through shareholder meetings, board } \\
\text { membership, and consultancy. }\end{array}$ \\
\hline $\begin{array}{l}\text { Freear, Sohl, } \\
\text { and Wetzel }\end{array}$ & 1995 & $\begin{array}{l}\text { Accounting data from } \\
284 \text { NTBFs and } \\
\text { interviews with } 124 \\
\text { entrepreneurs with } \\
\text { business angel as } \\
\text { investor. }\end{array}$ & $\begin{array}{l}\text { Business angels are involved } \\
\text { through representation on the board, } \\
\text { by being consultants, or directly } \\
\text { working for the venture. }\end{array}$ \\
\hline
\end{tabular}




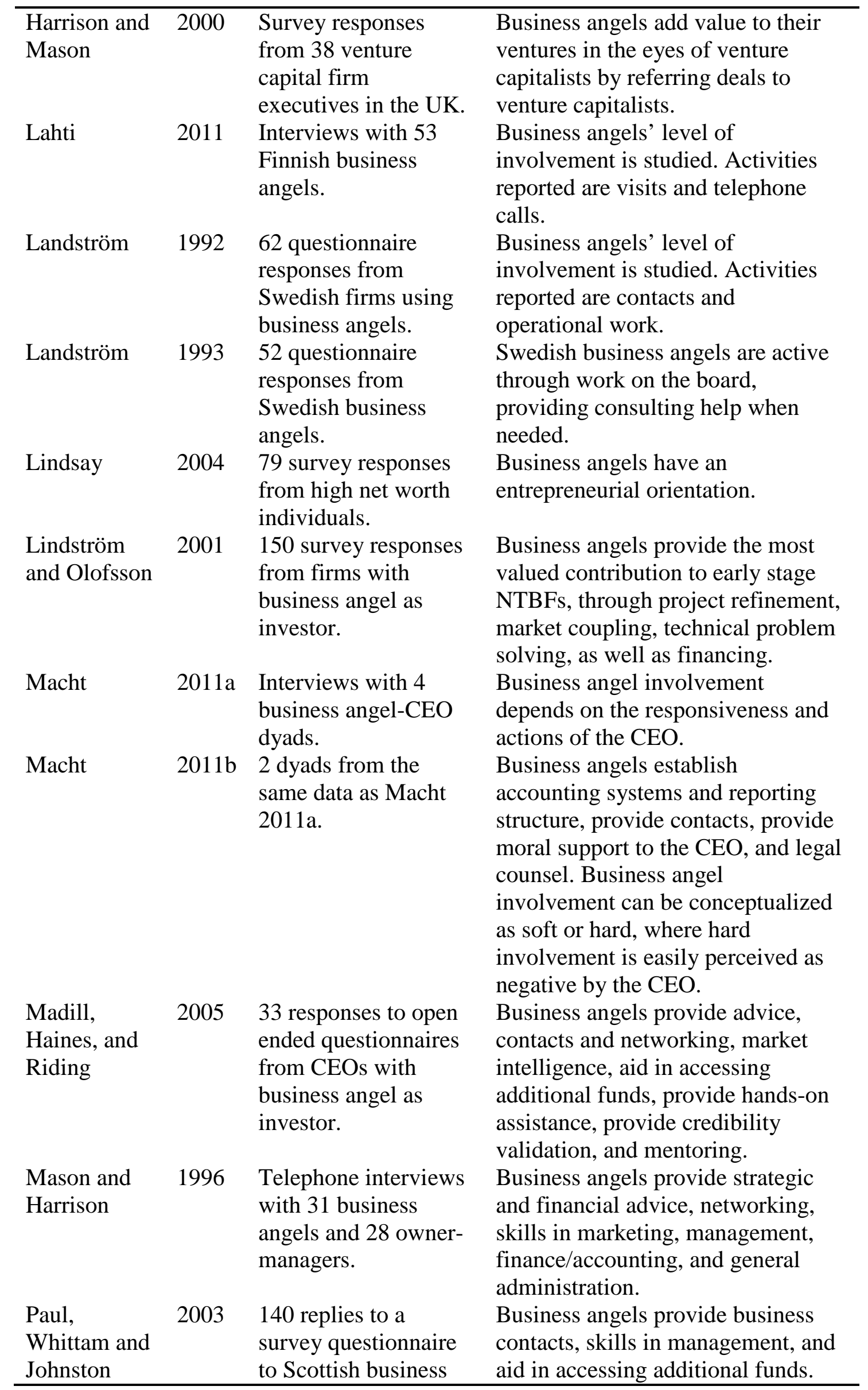




\begin{tabular}{|c|c|c|c|}
\hline & & angels. & \\
\hline $\begin{array}{l}\text { Paul, } \\
\text { Whittam and } \\
\text { Wyper }\end{array}$ & 2007 & $\begin{array}{l}30 \text { interviews with } \\
\text { Scottish business } \\
\text { angels. }\end{array}$ & $\begin{array}{l}\text { Business angels base their post- } \\
\text { investment activities on two } \\
\text { continuous processes; assessment of } \\
\text { venture and business angel } \\
\text { performance, and the process of the } \\
\text { personal relationship between the } \\
\text { business angel and the venture. }\end{array}$ \\
\hline $\begin{array}{l}\text { Politis and } \\
\text { Landström }\end{array}$ & 2002 & $\begin{array}{l}4 \text { interviews } \\
\text { performed with } 4 \\
\text { business angels (16 } \\
\text { interviews total). }\end{array}$ & $\begin{array}{l}\text { Business angels are involved as co- } \\
\text { entrepreneurs. }\end{array}$ \\
\hline Prowse & 1998 & $\begin{array}{l}12 \text { interviews with } \\
\text { business angels in } \\
\text { Texas. }\end{array}$ & $\begin{array}{l}\text { Business angels have founding } \\
\text { experience, management } \\
\text { experience, provide loans and loan } \\
\text { guarantees, aid in setting up } \\
\text { performance incentives, allocate } \\
\text { voting rights, aid in accessing } \\
\text { additional funds, recruit top } \\
\text { management and board members, } \\
\text { help solve major operational } \\
\text { problems, evaluate capital } \\
\text { expenditures, develop the } \\
\text { company's long-term strategy. They } \\
\text { are involved through board positions } \\
\text { or consultancy. }\end{array}$ \\
\hline $\begin{array}{l}\text { Reitan and } \\
\text { Sörheim }\end{array}$ & 2000 & $\begin{array}{l}425 \text { non-random } \\
\text { survey responses from } \\
\text { Norwegian business } \\
\text { angels. }\end{array}$ & $\begin{array}{l}\text { Business angels are involved } \\
\text { through board membership or } \\
\text { consultancy. }\end{array}$ \\
\hline Sætre & 2003 & $\begin{array}{l}20 \text { interviews with } \\
\text { entrepreneurs and } \\
\text { investors involved in } \\
4 \text { Norwegian firms. }\end{array}$ & $\begin{array}{l}\text { Business angels provide industry } \\
\text { networks, industry experience, aid } \\
\text { in accessing additional funds, affect } \\
\text { corporate strategy, influence } \\
\text { operational decisions, and provide } \\
\text { credibility. }\end{array}$ \\
\hline $\begin{array}{l}\text { Schäfer and } \\
\text { Schilder }\end{array}$ & 2009 & $\begin{array}{l}\text { Structured interviews } \\
\text { with } 11 \text { German } \\
\text { business angels. }\end{array}$ & $\begin{array}{l}\text { Business angels are involved in } \\
\text { strategic problems, network } \\
\text { advantages, business assessment } \\
\text { reports and consultancy. }\end{array}$ \\
\hline $\begin{array}{l}\text { Stedler and } \\
\text { Peters }\end{array}$ & 2003 & $\begin{array}{l}232 \text { non-random } \\
\text { survey responses from } \\
\text { German business } \\
\text { angels. }\end{array}$ & $\begin{array}{l}\text { Business angels provide hands-on } \\
\text { personal involvement, projected- } \\
\text { actual comparisons, cash flow } \\
\text { planning, annual reports, order } \\
\text { book. }\end{array}$ \\
\hline Sörheim & 2005 & $\begin{array}{l}5 \text { business angels in } \\
\text { Norway interviewed } \\
\text { twice ( } 10 \text { interviews } \\
\text { total). }\end{array}$ & $\begin{array}{l}\text { Business angels provide access to } \\
\text { additional funds. They are shown to } \\
\text { be members of the entrepreneurial } \\
\text { team. }\end{array}$ \\
\hline Tashiro & 1999 & 10 interviews with & Business angels provide general \\
\hline
\end{tabular}




\begin{tabular}{|c|c|c|c|}
\hline & & $\begin{array}{l}\text { Japanese business } \\
\text { angels on post- } \\
\text { investment activities. }\end{array}$ & $\begin{array}{l}\text { advice as an outside adviser or a } \\
\text { board member; and specific advice } \\
\text { regarding technology, human } \\
\text { resources, or finance. }\end{array}$ \\
\hline Wetzel & 1983 & $\begin{array}{l}\text { Interviews with } 133 \\
\text { business angels in } \\
\text { New England. }\end{array}$ & $\begin{array}{l}\text { Business angels are involved in the } \\
\text { board of directors, through } \\
\text { consultancy, or through full- or part- } \\
\text { time employment in the venture. }\end{array}$ \\
\hline $\begin{array}{l}\text { Wong, } \\
\text { Bhatia and } \\
\text { Freeman }\end{array}$ & 2009 & $\begin{array}{l}\text { Secondary data from } \\
215 \text { investment } \\
\text { rounds by angel } \\
\text { investors in } 143 \\
\text { companies. }\end{array}$ & $\begin{array}{l}\text { Business angels are vital for } \\
\text { procuring a management team and } \\
\text { procuring additional funds. }\end{array}$ \\
\hline
\end{tabular}


Table 4. Definitions of governance processes in the business angel-venture post investment relationship

\begin{tabular}{ll}
\hline Process & Level \\
Boundary spanning & Environment
\end{tabular}

Structuring

Leadership

Doing

Monitoring
Organization

Organization

Individual

Environment Organization Individual

\section{Definition}

Activities for managing and relating to the environment in capacities that are not part of regular venture operations. However, if the business angel is given formal responsibilities directed toward the environment in terms of venture operations (e.g., selling or marketing), such activities are not defined as boundary spanning; rather, these are seen as doing. Activities that specify roles, processes, and output in a systematic way with stability over time, for material or cognitive (internal identity and external legitimacy) reasons. Structuring also includes agenda setting and incentive schemes, because they specify outcomes of operational work. Most of the activities called "indirect leadership" (Hunt 1991; Yukl and Lepsinger 2004) are found here. However, short-term plans and monitoring activities are excluded. Activities performed during interaction with venture team members, aimed at influencing their behavior. It focuses on individual members through coaching, mentoring, and group leadership. Leadership is limited to interaction-based activities for influencing venture behavior (“direct leadership," Hunt 1991; Yukl and Lepsinger 2004), and excludes monitoring and structuring. Activities where the business angel is performing operational tasks that belong to daily venture operations (tasks including selling, marketing, production, R\&D, etc.). Activities that generate feedback for evaluating performance in handling both relational and market risk. They include formal management accounting systems as well as informal monitoring opportunities found during boundary spanning, leadership, and doing. 